\title{
POTENSI LAHAN BUDI DAYA TAMBAK DAN LAUT DI KABUPATEN MINAHASA, SULAWESI UTARA
}

\author{
A. Marsambuana Pirzan, Utojo, Muharijadi Atmomarsono, Muh. Tjaronge, \\ Abdul Malik Tangko, dan Hasnawi
}

\begin{abstract}
ABSTRAK
Penelitian dilakukan di kawasan pesisir Likupang, Kabupaten Minahasa, Sulawesi Utara bertujuan menelaah karakteristik lahan tambak dan laut untuk budi daya. Pengambilan contoh tanah, air, plankton, dan makrobentos di tambak dengan acak berlapis sederhana yang mewakili lokasi tambak dekat sawah/kebun, tambak di antara sawah/kebun dan bakau/pantai serta tambak dekat bakau/pantai. Di laut, pengambilan contoh air dan plankton yang mewakili lokasi perairan tanpa keramba jaring apung (KJA) (di pemukiman), lokasi KJA dekat pemukiman dan lokasi KJA yang jauh dari pemukiman. Pendugaan luas lahan yang berpotensi untuk dikembangkan sebagai budi daya tambak dan laut menggunakan teknologi Sistem Informasi Geografi (SIG). Secara global, lahan yang potensial dikembangkan untuk budi daya tambak, yaitu di lokasi dekat sawah/ kebun seluas 66,74 ha dan budi daya laut di lokasi yang jauh dari pemukiman seluas 246,13 ha.
\end{abstract}

ABSTRACT: Potential area for brackishwater pond and marine culture in Minahasa Regency, North Sulawesi. By: A. Marsambuana Pirzan, Utojo, Muharijadi Atmomarsono, Muh. Tjaronge, Abdul Malik Tangko, and Hasnawi

This research was conducted in the coastal area of Likupang, Minahasa Regency, North Sulawesi. The aimed of this research was to study the characteristic area for brackishwater pond and marine culture. Strafied random method sampling was applied for soil, water, plankton, and macrobenthos samples collected from representative brackishwater ponds (close to rice field, close to mangrove, and between both of them). Water samples was also collected from settleman area, floating net cages near and far from the settleman area. The Geographical Information System (GIS) was also used for prediction of potential area for brackishwater pond culture and marine culture. By global map, potential area possible for brackishwater pond culture close to the rice field was 66.74 ha, while for marine culture which is far from settleman area was 246.13 ha.

KEYWORDS: $\quad$ fish culture, brackishwater pond, marine culture, site selection

\section{PENDAHULUAN}

Budi daya tambak dan laut di kawasan pesisir Likupang, Kabupaten Minahasa, Sulawesi Utara berpeluang besar untuk dikembangkan sebagai usaha perikanan budi daya terpadu yang berlanjut. Di lokasi ini terdapat tambak yang berbatasan dengan Selat Likupang telah digunakan untuk pemeliharaan bandeng, ikan kuwe, dan udang secara tradisional plus. Selanjutnya di laut pembudi daya ikan telah merintis pemeliharaan ikan kuwe di dalam keramba jaring apung (KJA). Akhir-akhir ini Dinas Perikanan dan Kelautan Kabupaten Minahasa, Sulawesi Utara telah mencoba melakukan paket percontohan Intensifikasi Budi Daya Ikan (Inbudkan) kerapu di dalam KJA. Lokasi seperti ini sangat memungkinkan untuk usaha integrasi antara budi daya tambak dan laut yang berkelanjutan.

Pengembangan budi daya tambak dan laut di lokasi ini perlu penguasaan Iptek dalam memanfaatkan sumber daya, sehingga tidak menimbulkan masalah limbah pakan dan feses yang berdampak negatif terhadap lingkungan. Dampak tersebut biasanya dicirikan oleh kegiatan budi daya yang dihasilkan dari perencanaan yang kurang mantap, kesalahan pemilihan lokasi, penerapan prosedur manajemen budi daya yang kurang tepat serta kurangnya perhatian terhadap lingkungan. Beban cemaran dari KJA bandeng yang terbuang ke lingkungan perairan masing-masing mencapai 43,56 $\mathrm{kg}$ nitrogen; $31,00 \mathrm{~kg}$ fosfor; dan 148,41 kg karbon per ton produksi ikan di Teluk Awarange (Rachmansyah et al., 2003). Dampak lebih lanjut, seperti terjadinya hipernutrifikasi yang diikuti oleh perubahan ekologi seperti peningkatan sedimentasi, siltasi, hypoxia, perubahan produktivitas fitoplankton, dan struktur komunitas bentos (Barg, 1992) yang dapat merusak keberlanjutan manfaat sumber daya dan lingkungan hidup perikanan. 
Usaha budi daya ikan di tambak dan laut yang berlanjut perlu karakterisasi biofisik lahan sebelum memulai usaha tersebut, sehingga dampak negatif terhadap lingkungan dapat diminimalkan. Dampak tersebut utamanya disebabkan oleh ulah manusia, yaitu melakukan praktek budi daya yang destruktif dan eksploitasi sumber daya yang berlebih. Hal ini akan mempengaruhi kondisi biotik dan abiotik lahan yang mengarah kepada penurunan biodiversitas yang dicirikan oleh komunitas biota yang labil. Untuk mewujudkan usaha budi daya yang berlanjut, maka telaah karakteristik biofisik lahan untuk budi daya penting dilakukan.

\section{BAHAN DAN METODE}

Penelitian dilakukan pada bulan Desember 2003 di kawasan pesisir Likupang, Kabupaten Minahasa, Sulawesi Utara. Pengambilan contoh tanah, air, plankton, dan makrobentos secara acak berlapis sederhana (Bengen, 2000). Pengambilan contoh tersebut dilakukan dengan tujuan untuk menentukan present status perairan yang terkait dengan karakterisasi habitat bagi kehidupan ikan budi daya. Stasiun pengambilan contoh tanah, air, plankton, dan makrobentos di kawasan tambak dan laut ditentukan posisi geografisnya dengan menggunakan Geographical Positioning System (GPS). Stasiun di kawasan tambak, yaitu tambak dekat sawah/kebun (St.1), tambak di antara sawah dan bakau/pantai (St. 2), dan tambak dekat bakau/pantai (St. 3), sedangkan di kawasan laut pengambilan contoh air dan plankton dilakukan di lokasi pemukiman (tanpa keramba jaring apung) (St. 4), lokasi KJA dekat pemukiman (St. 5), dan lokasi KJA jauh dari pemukiman (St. 6) (Gambar 1).

Luas lahan yang potensial untuk budi daya tambak dan laut diperoleh dari pengolahan dan analisis data primer dan sekunder menggunakan teknologi Sistem Informasi Geografi (SIG) (Purwadhi et al., 1997) dengan cara menumpangsusunkan (overlay) setiap variabel yang menjadi kriteria kelayakan lahan. Pengamatan variabel kimia air mencakup $\mathrm{NH}_{4}-\mathrm{N}, \mathrm{NO}_{3}-\mathrm{N}, \mathrm{NO}_{2}-\mathrm{N}$, $\mathrm{SO}_{4} \mathrm{Fe}$, dan $\mathrm{PO}_{4}-\mathrm{P}$ dengan spektrofotometer (Haryadi et al., 1992). Kualitas tanah yang diamati adalah $\mathrm{pH}$ $\left(\mathrm{KCl}\right.$ dan $\mathrm{H}_{2} \mathrm{O}$ ), bahan organik, nitrat, $\mathrm{Fe}$, dan tekstur tanah (Menon, 1973). Variabel biologi meliputi: plankton dikoleksi dengan menggunakan plankton net No. 25, diidentifikasi berpedoman pada Newel \& Newel (1977) dan Yamaji (1976) serta kelimpahannya menggunakan rumus counting cell (APHA, 1998). Makrobentos dikoleksi dengan menggali tanah berukuran $25 \times 25 \times 10 \mathrm{~cm}^{3}$ (Hily et al., 1994). Sampel tersebut kemudian disaring menggunakan sieve net No. 32 (Ueda et al., 1994) dan identifikasinya berdasarkan kunci determinasi Anonymous (1982), Abbott (1991), dan Dharma (1988; 1992). Indeks keragaman, keseragaman, dan dominansi plankton dan makrobentos dihitung berdasarkan modifikasi metode Odum (1963).

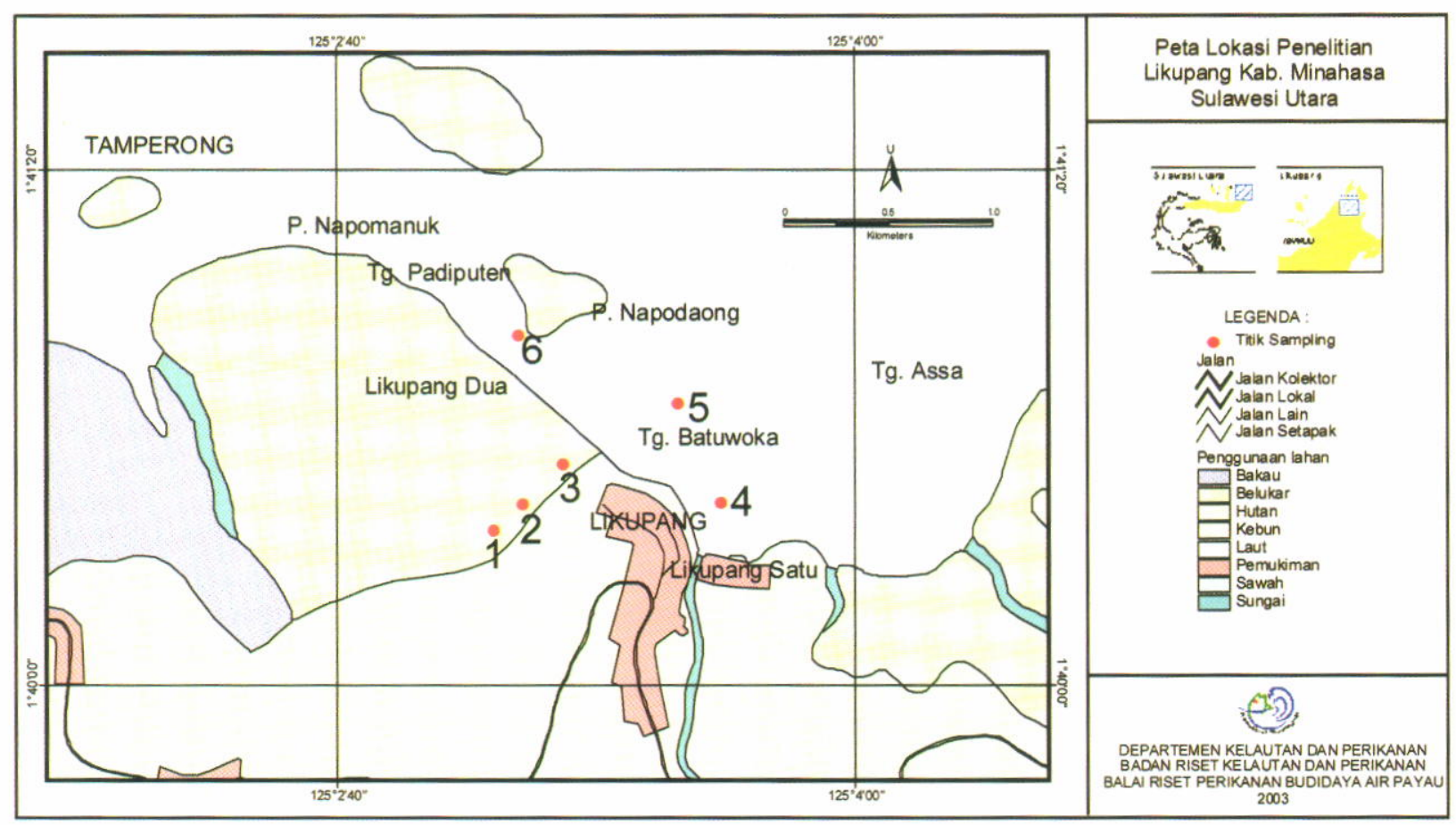

Gambar 1. Lokasi riset di Likupang Kabupaten Minahasa, Sulawesi Utara

Figure 1. Research location in Likupang Minahasa Regency, North Sulawesi 


\section{HASIL DAN BAHASAN}

Berdasarkan kondisi pada bulan Desember 2003, di lokasi penelitian terdapat kegiatan budi daya tambak secara tradisional plus dan budi daya ikan KJA. Karakterisasi biofisik lahan budi daya sangat diperlukan sebagai acuan persyaratan kelayakan bagi kehidupan ikan. Besaran peubah-peubah tersebut disajikan pada Tabel 1 .

\section{Tambak}

Kabupaten Minahasa memiliki garis pantai sekitar $525 \mathrm{~km}$ (Anonim, 2003b), luas tambak 141 ha (Anonim, 2002), dan berdasarkan hasil kajian perwilayahan komoditas, lahan yang potensial untuk budi daya tambak seluas 449 ha. Komoditas ikan budi daya yang dikembangkan adalah ikan bandeng, Chanos chanos untuk tujuan konsumsi dan sebagai umpan hidup, sedangkan komoditas udang untuk ekspor sebagai penghasil devisa negara. Salah seorang petambak di Likupang juga telah mencoba memelihara ikan kuwe di tambaknya. Nener diperoleh di sekitar lokasi budi daya dan sebagian dibeli dari penampung di Manado dan Gorontalo atau dari Gondol-Bali, sedangkan benur didatangkan dari Surabaya. Berdasarkan data tabular dan spasial (peta) berupa: Peta Rupa Bumi Indonesia, Peta Lingkungan Pantai Indonesia, dan Atlas Sumber Daya Wilayah Pesisir Minahasa-Manado-Bitung, Sulawesi Utara, maka luas lahan yang potensial untuk budi daya tambak di lokasi penelitian seluas 66,74 ha (Gambar 2). Kriteria yang menjadi pertimbangan dalam memperoleh luasan tersebut adalah berdasarkan data ketinggian dan penggunaan lahan. Lokasi ini berupa belukar dan sawah yang berbatasan dengan areal pertambakan di mana pada saat pasang masih terpengaruh oleh air asin. Karakteristik biofisik dan kimia lahan diuraikan sebagai berikut.

Kelimpahan plankton di tambak Likupang berkisar dari 30-450 ind./L relatif lebih rendah dibandingkan dengan di tambak Mamuju (mangrove luas) 15-1.510 ind./L, di Luwu Utara (mangrove lebat dan luas) 20820 ind./L, dan di Sinjai (mangrove artifisial TongkeTongke) 10-840 ind./L (Pirzan et al., 2003). Hal ini diduga karena pengaruh limbah yang berasal dari perkampungan nelayan dan tempat kapal berlabuh. Indeks keragaman plankton di tambak Likupang berkisar dari 0,32-0,91. Berdasarkan Stirn (1981), nilai $\mathrm{H} !<1$ menunjukkan bahwa lokasi tersebut berada

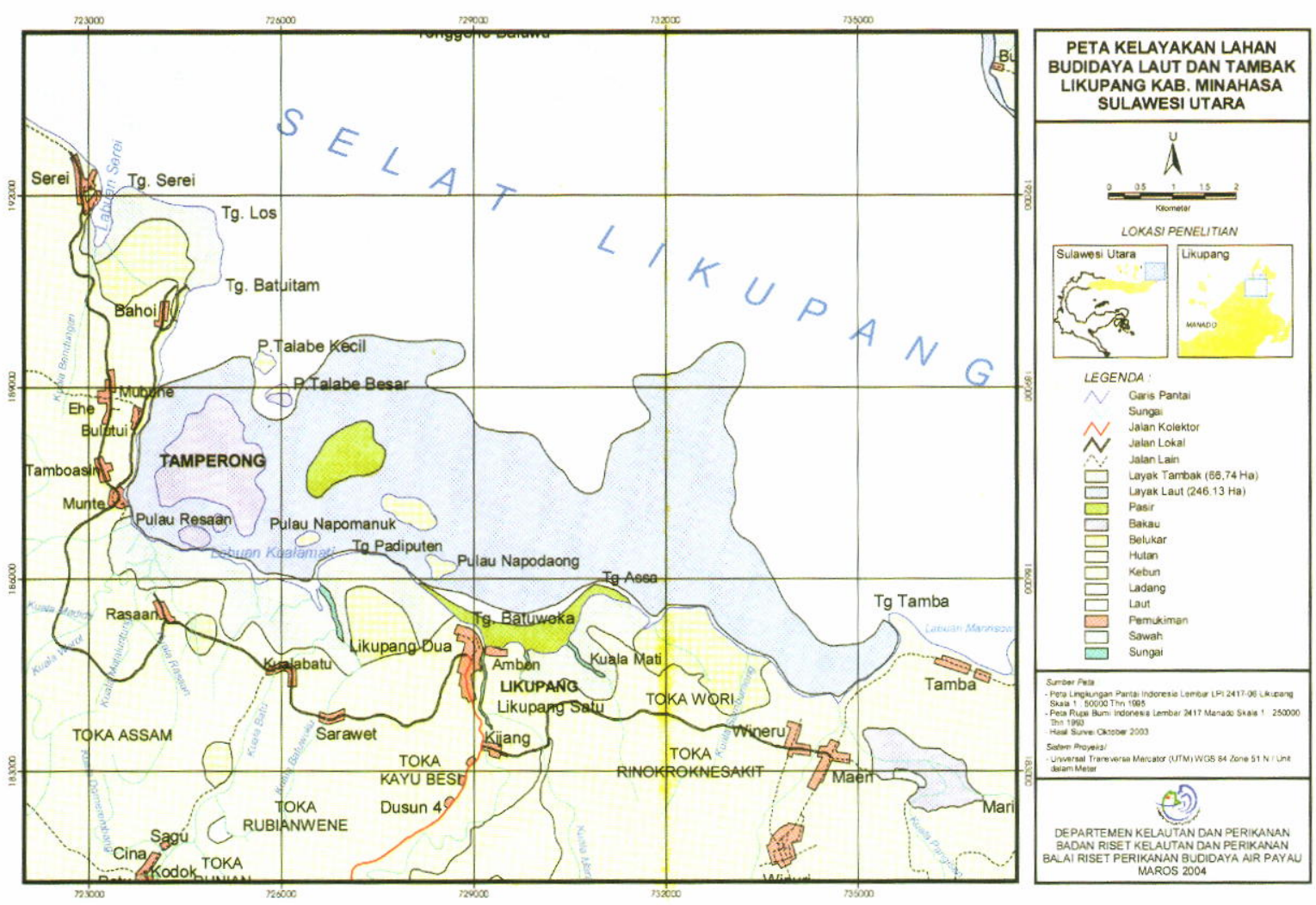

Gambar2. Lahan yang potensial untuk budi daya tambak dan laut di Likupang, Kabupaten Minahasa, Sulawesi Utara

Figure 2. Potential area for brackishwater pond and marine culture in Likupang, Minahasa Regency, North Sulawesi 
Tabel 1. Karakteristik biofisik dan kimia kawasan pesisir Likupang Kabupaten Minahasa, Sulawesi Utara Table 1. Biological and chemical characteristics of Likupang coastal area, Minahasa Regency, North Sulawesi

\begin{tabular}{|c|c|c|}
\hline $\begin{array}{l}\text { Peubah } \\
\text { Variable }\end{array}$ & $\begin{array}{l}\text { Kisaran } \\
\text { Range }\end{array}$ & $\begin{array}{l}\text { Nilai rataan } \\
\text { Average value }\end{array}$ \\
\hline \multicolumn{3}{|l|}{ Tambak (Brackishwater pond) } \\
\hline \multicolumn{3}{|l|}{ a. Biologi (Biology) } \\
\hline \multicolumn{3}{|l|}{ - Plankton } \\
\hline Jumlah jenis (Species number) & $2-3$ & $(2.6 \pm 0.4)$ \\
\hline Kelimpahan (Abundance) (Ind./L) & $30-450$ & $(207.5 \pm 156.2)$ \\
\hline Indeks keragaman (Diversity indices) & $0.32-0.91$ & $(0.68 \pm 0.26)$ \\
\hline Indeks keseragaman (Evenness indices) & $0.47-0.82$ & $(0.67 \pm 0.14)$ \\
\hline Indeks dominansi (Dominance indices) & $0.47-0.82$ & $(0.60 \pm 0.15)$ \\
\hline \multicolumn{3}{|l|}{ - Makrobentos (Macrobenthos) } \\
\hline Jumlah jenis (Species number) & $2-3$ & $(2.6 \pm 0.5)$ \\
\hline Kepadatan (Density) (Ind. $/ 625 \mathrm{~cm}^{2}$ ) & $1-4$ & $(1.6 \pm 0.9)$ \\
\hline Indeks keragaman (Diversity indices) & $0.63-1.08$ & $(0.92 \pm 0.20)$ \\
\hline Indeks keseragaman (Evenness indices) & $0.91-0.99$ & $(0.95 \pm 0.03)$ \\
\hline Indeks dominansi (Dominance indices) & $0.33-0.55$ & $(0.41 \pm 0.10)$ \\
\hline \multicolumn{3}{|l|}{ b. Kimia (Chemical) } \\
\hline \multicolumn{3}{|l|}{ - Air (Water) } \\
\hline BOT $(\mathrm{mg} / \mathrm{L})$ & $7.35-11.36$ & $(9.13 \pm 1.67)$ \\
\hline $\mathrm{NO}_{2}-\mathrm{N}(\mathrm{mg} / \mathrm{L})$ & $0.0438--0.0456$ & $(0.0446 \pm 0.0008)$ \\
\hline $\mathrm{NO}_{3}-\mathrm{N}(\mathrm{mg} / \mathrm{L})$ & $0.1969--0.6658$ & $(0.2575 \pm 0.2450)$ \\
\hline $\mathrm{NH}_{4}-\mathrm{N}(\mathrm{mg} / \mathrm{L})$ & $0.5269-1.1225$ & $(0.7450 \pm 0.2680)$ \\
\hline $\mathrm{SO}_{4}(\mathrm{mg} / \mathrm{L})$ & $26.798-43.211$ & $(34.735 \pm 6.711)$ \\
\hline $\mathrm{Fe}(\mathrm{mg} / \mathrm{L})$ & $0.1173--0.1544$ & $(0.1354 \pm 0.0152)$ \\
\hline $\mathrm{PO}_{4}-\mathrm{P}(\mathrm{mg} / \mathrm{L})$ & $0.2360-0.2505$ & $(0.2432 \pm 0.0060)$ \\
\hline \multicolumn{3}{|l|}{ c. Fisika (Physical) } \\
\hline \multicolumn{3}{|l|}{ - Tanah (Soil) } \\
\hline Pasir (Sand) (\%) & $70-80$ & $(75 \pm 5)$ \\
\hline Liat (Clay) (\%) & $0--4$ & $(2 \pm 2)$ \\
\hline Debu (Silt) $(\%)$ & $20--26$ & $(23 \pm 3)$ \\
\hline \multicolumn{3}{|l|}{ Laut (Sea) } \\
\hline \multirow{2}{*}{\multicolumn{3}{|c|}{$\begin{array}{l}\text { a. Biologi (Biology) } \\
\text { - Plankton }\end{array}$}} \\
\hline & & \\
\hline Jumlah jenis (Species number) & $2-5$ & $(3.7 \pm 1.2)$ \\
\hline Kelimpahan (Abundance) (Ind./L) & $20-1,300$ & $(266.4 \pm 364.1)$ \\
\hline Indeks keragaman (Diversity indices) & $0.30-0.93$ & $(0.66 \pm 0.27)$ \\
\hline Indeks keseragaman (Evenness indices) & $0.44--0.67$ & $(0.53 \pm 0.10)$ \\
\hline Indeks dominansi (Dominance indices) & $0.46--0.83$ & $(0.65 \pm 0.15)$ \\
\hline \multicolumn{3}{|l|}{ b. Kimia (Chemical) } \\
\hline \multicolumn{3}{|l|}{ - Air (Water) } \\
\hline BOT (mg/L) & $3.34-33.40$ & $(15.36 \pm 12.99)$ \\
\hline $\mathrm{NO}_{2}-\mathrm{N}(\mathrm{mg} / \mathrm{L})$ & $0.0431-0.0434$ & $(0.0433 \pm 0.0001)$ \\
\hline $\mathrm{NO}_{3}-\mathrm{N}(\mathrm{mg} / \mathrm{L})$ & $0.1292--0.2251$ & $(0.1907) \pm 0.0436)$ \\
\hline $\mathrm{NH}_{4}-\mathrm{N}(\mathrm{mg} / \mathrm{L})$ & $0.3468--0.3518$ & $(0.3545 \pm 0.0076)$ \\
\hline $\mathrm{SO}_{4}(\mathrm{mg} / \mathrm{L})$ & $24.236--37.898$ & $(32.786 \pm 5.635)$ \\
\hline $\begin{array}{l}\mathrm{Fe}(\mathrm{mg} / \mathrm{L}) \\
\mathrm{PO}_{4}-\mathrm{P}(\mathrm{mg} / \mathrm{L})\end{array}$ & $\begin{array}{c}0.079-0.096 \\
0.2374-0.2792\end{array}$ & $\begin{array}{c}(0.087 \pm 0.007) \\
(0.0252 \pm 0.0195)\end{array}$ \\
\hline
\end{tabular}


dalam kondisi komoditas biota yang tidak stabil, di mana komunitas bersangkutan sedang mengalami gangguan faktor lingkungan akibat adanya limbah domestik dan polutan kapal nelayan yang merembes ke dalam tambak. Penyebab utama berkurangnya biodiversitas atau lenyapnya spesies adalah perusakan habitat alami, pencemaran, dan perubahan iklim (Widodo, 1997). Nilai indeks keseragaman di tambak Likupang 0,47-0,82 (rataan 0,67) relatif sama dengan indeks keseragaman di tambak Mamuju antara 0,120,99 (rataan 0,71), Luwu Utara 0,33-0,99 (rataan 0,71 ), dan Sinjai antara 0,58-0,99 (rataan 0,83). Hal ini mencerminkan kekayaan spesies yang dimiliki masing-masing spesies dapat dikatakan relatif merata atau perbedaannya tidak menyolok (Lind, 1991). Indeks dominansi di tambak Likupang berkisar antara 0,47-0,82 menunjukkan tidak ada spesies yang mendominasi di perairan tersebut.

Jenis dan kepadatan makrobentos di Likupang masing-masing $2-3$ taksa dan $1-4$ ind. $/ 625 \mathrm{~cm}^{2}$ relatif lebih rendah dibandingkan dengan di kawasan tambak dan mangrove Luwu Utara, Mamuju, dan SinjaiSulawesi Selatan, yaitu 1-23 jenis dan kepadatan 1150 ind. $/ 625 \mathrm{~cm}^{2}$ (Pirzan et al., 2001; Pirzan \& Gunarto, 2001). Indeks keragaman makrobentos di tambak dekat sawah/kebun 1,08 dan tambak di antara sawah dan bakau $(1,05)$, komunitas biotanya termasuk stabil moderat yang mudah berubah hanya dengan pengaruh lingkungan yang relatif kecil. Selanjutnya tambak dekat bakau/pantai, nilai indeks keragaman 0,63 di mana komunitas biotanya termasuk labil (komunitas sedang mengalami gangguan faktor lingkungan), kemungkinan karena pengaruh limbah domestik dan bahan bakar kapal. Nilai keseragaman makrobentos di tambak Likupang, pada stasiun dekat sawah/kebun $(0,99)$, stasiun tambak di antara sawah dan bakau $(0,96)$, dan stasiun dekat bakau/pantai $(0,91)$ tergolong tinggi dengan nilai E>75 (Ali, 1994). Menurut Basmi (2000), bila nilai keseragaman mendekati 0 , berarti keseragaman antar spesies di dalam komunitas adalah rendah, sebaliknya bila mendekati 1 dapat dikatakan keseragaman antar spesies relatif merata atau relatif sama. Indeks dominansi di tambak, cenderung semakin tinggi ke arah pantai, yaitu berturut-turut stasiun tambak dekat sawah $(0,33)$, tambak di antara sawah dan bakau $(0,37)$, dan tambak dekat bakau/pantai $(0,55)$, peningkatan tersebut seiring dengan meningkatnya kandungan BOT di dalam air.

Kualitas tanah aktual di lokasi penelitian, menunjukkan bahwa kandungan bahan organik tanah termasuk tinggi $(10,78 \%-44,65 \%)$. Kandungan bahan organik tanah yang layak bagi pertumbuhan pakan alami di tambak adalah 9\% (Kahar et al., 1991). Kandungan bahan organik $>16 \%$ akan memacu pertumbuhan alga sangat melimpah (Anonim, 1978).
Tekstur tanah berhubungan dengan pertumbuhan pakan alami termasuk makrobentos di tambak. Beberapa studi menunjukkan bahwa organisme bentik dapat memodifikasi karakteristik substrat (Quijon \& Jarnillo, 1993). Perbedaan karakteristik tekstur berhubungan erat dengan dinamika erosi dan endapan (Roads \& Royer dalam Quijon \& Jarnillo, 1993). D lokasi penelitian kandungan pasir termasuk tinggi, yaitu berkisar dari $70 \%-80 \%$. Kandungan pasir $15 \%$ berindikasi pada pertumbuhan pakan alami yang melimpah, kandungan pasir 63\% akan terjadi pertumbuhan pakan alami menipis dan kandungan pasir $79 \%$ dengan pertumbuhan sangat menipis (Anonim, 1978). Kandungan liat di lokasi penelitian tergolong rendah, yaitu berkisar $0 \%-4 \%$. Selanjutnya kandungan debu di lokasi penelitian (20\%-26\%) termasuk cukup (Anonim, 1978). Tekstur tanah tambak seperti ini, pengisian air lebih sering dan ketinggian air lebih cepat turun, sehingga memerlukan sistem pengairan yang prima dan konstruksi pematang harus kuat dan kedap air. Sistem irigasi tambak di lokasi ini, yaitu mengandalkan selisih pasang tertinggi dan surut terendah $(80 \mathrm{~cm})$ melalui sungai kecil (creek) yang ada di kawasan tersebut.

Hasil analisis kualitas tanah, secara umum menunjukkan bahwa $\mathrm{pH} \mathrm{KCl}$ dan $\mathrm{pH} \mathrm{H}_{2} \mathrm{O}$ tanah di lokasi penelitian tergolong rendah $(4,24-5,44)$. Kondisi $\mathrm{pH}$ rendah, unsur fosfor dan kalium dalam keadaan terikat sehingga sulit dimanfaatkan oleh pakan alami yang berpengaruh terhadap produksi tambak.

Kandungan Fe dalam air (0,1173-0,1544 mg/L) relatif tinggi dibandingkan dengan kandungan di perairan alami, yaitu dengan kisaran nilai 0,01780,0966 mg/L, sedangkan menurut Boyd (1990), bahwa konsentrasi Fe di perairan berkisar 0,05-0,2 mg/L. Selanjutnya kandungan $\mathrm{NH}_{4}-\mathrm{N}$ dengan nilai kisaran $0,5269-1,1225 \mathrm{mg} / \mathrm{L}$ dan $\mathrm{NO}_{3}-\mathrm{N}$ dengan nilai kisaran $0,1969-0,6658 \mathrm{mg} / \mathrm{L}$, termasuk tinggi. Meade dalam Boyd (1990) menyatakan bahwa amonia yang diizinkan untuk ikan budi daya umumnya dapat mencapai 0,012 mg/L. Selanjutnya disebutkan bahwa amonia dan amonium menimbulkan toksik bagi organisme budi daya, tetapi amonia lebih toksik daripada amonium. Kandungan $\mathrm{NO}_{2}-\mathrm{N}$, yaitu berkisar dari 0,0431-0,0456 mg/L. Konsentrasi nitrit yang aman untuk post larva pada kolam pembesaran adalah $4,5 \mathrm{mg} / \mathrm{L}$ (Chen Chin dalam Boyd, 1990) sehingga nilai tersebut masih layak mendukung kehidupan dan pertumbuhan organisme budi daya. Kandungan $\mathrm{PO}_{4}$ $P$ berkisar 0,2360-0,2505 $\mathrm{mg} / \mathrm{L}$ lebih tinggi dibandingkan dengan di kawasan tambak Mamuju, yaitu berkisar dari 0,0293-0,2491 mg/L; Luwu Utara $0.0017-0,0091 \mathrm{mg} / \mathrm{L}$; dan Sinjai 0,1188-0,1986 mg/ $\mathrm{L}$ (Pirzan et al., 2003). Nilai tersebut sejalan dengan 
pernyataan Boyd (1990) bahwa konsentrasi total posfat dalam perairan jarang melampaui $1 \mathrm{mg} / \mathrm{L}$.

\section{Laut}

Di lokasi penelitian telah berkembang budi daya ikan laut di dalam KJA sebanyak 18 unit. Komoditas ikan budi daya yang dikembangkan adalah ikan kuwe (Caranx spp.), kerapu tikus (Cromileptes altivelis), dan kerapu macan (Epinephelus fuscoguttatus) yang dilakukan baik oleh perorangan/kelompok pembudi daya ikan maupun oleh pengusaha. Benih ikan budi daya yang diperoleh pada lokasi budi daya adalah ikan kuwe sedangkan ikan kerapu tikus dan kerapu macan berasal dari Lampung, Gondol-Bali dan Situbondo-Jawa Timur.

Berdasarkan data tabular maupun data spasial maka luas areal yang dapat dikembangkan untuk budi daya ikan di dalam KJA di lokasi penelitian yang jauh dari pemukiman seluas 246,13 ha (Gambar 2). Kriteria utama menjadi pertimbangan untuk memperoleh luasan tesebut berdasarkan peta batimetri keterlindungan. Lokasi ini berupa teluk yang berhadapan dengan $\mathrm{P}$. Bangka, P. Gangga, dan P. Talise serta karakteristik biofisik dan kimianya diuraikan sebagai berikut.

Jenis plankton yang ditemukan bervariasi dari 25 jenis dengan kepadatan $20-1.300$ ind./L. Di perairan Kepulauan Togean, didapatkan bahwa banyaknya taksa plankton yang ditemukan pada setiap lokasi bervariasi dari 4-15 taksa dan kepadatannya bervariasi dari 11-112 ind./L (Anonim, 2003a). Jenis plankton yang ditemukan di lokasi penelitian lebih rendah dibandingkan dengan di Kepulauan Togean, karena pengaruh dari daratan lebih tinggi daripada Kepulauan Togean. Indeks keragaman plankton bervariasi dari 0,30-0,93; indeks keseragaman 0,440,67 ; dan indeks dominansi $0,46-0,83$. Berdasarkan indeks keragaman plankton di lokasi penelitian, maka komunitas biotanya termasuk labil (Basmi, 2000) karena memiliki nilai $\mathrm{H} !<1$. Indeks keseragaman plankton antar spesies dapat dikatakan relatif merata dan dominansinya tidak menunjukkan adanya spesies yang secara ekstrim mendominasi spesies lainnya.

Kandungan $\mathrm{NH}_{4}-\mathrm{N}$ berkisar dari 0,3468-0,3518

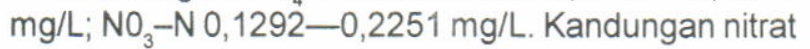
yang diperoleh lebih tinggi dibandingkan dengan di kepulauan Togean $(0,07-0,08 \mathrm{mg} / \mathrm{L})$ yang dapat mempengaruhi ikan budi daya (Anonim, 2003a). Kandungan $\mathrm{PO}_{4}-\mathrm{P}$ berkisar dari 0,2374-0,2792 mg/ $L$ lebih tinggi dibandingkan dengan kandungan fosfat di perairan Batanghari Hilir-Jambi, yaitu berkisar $0,12-0,19 \mathrm{mg} / \mathrm{L}$. Kandungan tersebut sudah dapat menyebabkan penyuburan perairan dan sewaktuwaktu diikuti oleh adanya blooming fitoplankton di perairan setempat (Samuel et al., 1995).
Secara umum, kualitas lingkungan perairan Likupang terdapat peubah-peubah yang relatif tinggi, seperti fosfat dan nitrat yang dapat mempengaruhi keberhasilan usaha budi daya biota laut. Mengatasi hal tersebut perlu melakukan konservasi mangrove, terumbu karang, dan padang lamun di sekitar lokasi budi daya untuk perbaikan kualitas lingkungan dan eliminasi proses penyuburan perairan akibat buangan limbah dari kegiatan budi daya dan non budi daya. Keberadaan mangrove yang luas di sekitar lokasi budi daya dapat menyebabkan keragaman makrobentos lebih tinggi (kestabilan tinggi) bila dibandingkan dengan lokasi yang di sekitarnya hanya mempunyai areal mangrove yang sempit (Gunarto at al., 2002). Ekosistem yang memiliki biodiversitas tinggi lebih stabil dan kurang terpengaruh terhadap tekanan dari luar dibandingkan dengan ekosistem yang memiliki biodiversitas rendah (Boyd, 1999) yang dapat mendukung usaha budi daya yang berlanjut.

Teknologi budi daya yang dapat dikembangkan di lokasi ini adalah budi daya ikan di dalam KJA karena kondisi lingkungan mendukung. Lokasi ini merupakan selat sehingga musim angin dan gelombang relatif tidak merupakan faktor pembatas bagi pengembangan usaha budi daya dalam KJA. Secara lokal, arus di lokasi ini banyak dipengaruhi oleh bentuk topografi pesisir pantai dan juga pasang surut sehingga pada tingkat ini arus dan pasang surut menentukan arah dan kecepatan arus lokal. Pada saat penelitian, masyarakat setempat telah mencoba budi daya ikan kuwe dalam KJA baik dilakukan secara perorangan maupun secara kelompok. Di lokasi ini, Dinas Perikanan dan Kelautan Minahasa juga telah melakukan paket percontohan Inbudkan kerapu untuk mendukung pengembangan budi daya dalam KJA. Selain itu, komoditas strategis lainnya yang dapat dikembangkan adalah ikan bandeng karena lokasi ini dekat dengan areal pertambakan yang dapat dijadikan tempat penghasil gelondongan untuk memasok benih bagi kebutuhan di KJA yang menghasilkan bandeng konsumsi, bandeng super atau bandeng induk. Masalah pemasaran hasil panen tidak menjadi hambatan karena hubungan dengan kota-kota kabupaten dan provinsi mudah dan lancar serta ditunjang oleh adanya pasar dan tempat pelelangan ikan di lokasi ini.

\section{KESIMPULAN DAN SARAN}

Berdasarkan telaah karakteristik lahan yang dilakukan maka dapat dikemukakan hal-hal sebagai berikut:

1. Secara global lahan yang potensial dikembangkan untuk budi daya tambak, yaitu di lokasi dekat sawah/kebun seluas 66,74 ha dan budi daya laut 
di lokasi yang jauh dari pemukiman seluas 246,13 ha.

2. Keragaman plankton $(0,91)$ dan makrobentos $(1,08)$ di stasiun tambak dekat sawah/kebun, komunitas biotanya tergolong stabil moderat, sedangkan stasiun tambak di antara sawah dan bakau serta dekat bakau/pantai tergolong labil.

3. Keragaman plankton di laut, yaitu stasiun di pemukiman (tanpa KJA) $(0,75)$, lokasi KJA dekat pemukiman $(0,92)$, dan lokasi KJA yang jauh dari pemukiman $(0,32)$ tergolong labil.

4. Perlu dilakukan konservasi mangrove, terumbu karang, dan padang lamun di sekitar lokasi budi daya guna perbaikan kualitas lingkungan terutama dalam hal pencegahan proses penyuburan perairan akibat limbah budi daya dan aktivitas lainnya.

\section{DAFTAR PUSTAKA}

Abbott, R.T. 1991. Shells of South Asia. Tynron. Press, Scotland, $145 \mathrm{pp}$.

Ali, I.M. 1994. Struktur Komunitas Ikan dan Aspek Biologi Ikan-Ikan Dominan di Danau Sidenreng, Sulawesi Selatan. Thesis Sarjana. Fak. Perikanan, Institut Pertanian Bogor. Bogor.

Anonim. 1978. Manual on Pond Culture of Penaeid Shrimp. ASEAN National Coordinating Agency of the Philippines. Manila, $122 \mathrm{pp}$.

Anonymous. 1982. The Macdonald Encylopedia of Shells. Macdonald \& Co. London \& Sydney, 512 pp.

Anonim. 2002. Sulawesi Utara dalam Angka. Badan Pusat Statistik Provinsi Sulawesi Utara - Pemerintah Daerah Provinsi Sulawesi Utara. Manado, 435 pp.

Anonim. 2003a. Atlas Sumber Daya Wilayah Pesisir Utara Kabupaten Donggala dan Kepulauan Togean. Badan Perencanaan Pembangunan Prop. Sulawesi Tengah, $84 \mathrm{pp}$.

Anonim. 2003b. Atlas Sumber Daya Wilayah Pesisir Minahasa-Manado-Bitung Sulawesi Utara. Pemerintah Provinsi Sulawesi Utara (Kabupaten Minahasa, Kota Manado dan Kota Bitung), 92 pp.

APHA. 1998. Standard Methods for the Examination of Water and Waste Water. In Clesseri, L.S., A.E. Greenberg, and A.D. Eaton (Eds.). American Public Health Association. $20^{\text {th }}$ edition.

Barg, U.C. 1992. Guidelines of the promotion of environmental management of coastal aquaculture development. FAO Fisheries Technical Paper 328 $F A O$, Rome, 131 pp.

Basmi, J. 2000. Planktonlogi: Plankton sebagai Indikator kualitas perairan. Fak. Perikanan dan IImu Kelautan. Institut Pertanian Bogor, 60 pp.

Bengen, D.G. 2000. Teknik Pengambilan Contoh dan Analisis data Biofisik Sumber Daya Pesisir. Fakultas Perikanan dan IImu Kelautan. Institut Pertanian Bogor, Bogor, $88 \mathrm{pp}$.

Beveridge, M.C.M. 1987. Cage and pen farming: carrying capacity models and environmental impact. FAO Fish.TECH. Pap. 255.FIRI/T255, 131 pp.
Boyd, C.E. 1990. Water Quality in Ponds for Aquaculture. Alabama Agricultural Experiment Station. Auburn University, Alabama, $482 \mathrm{pp}$.

Boyd, C.E. 1999. Code of Practice for Responsible Shrimp Farming. Global Aquaculture Alliance, St. Louis, MO, USA, 42 pp.

Dharma, B. 1988. Siput dan Kerang Indonesia (Indonesian Shell). PT Sarana, Jakarta, 111 pp.

Dharma, B. 1992. Siput dan Kerang Indonesia (Indonesian Shells II). Verlag Christa Hemmen. Germany, $134 \mathrm{pp}$.

Gunarto, A.M. Pirzan, Suharyanto, Daud R., dan Burhanuddin. 2002. Pengaruh keberadaan mangrove terhadap keragaman makrobentos di tambak sekitarnya. J. Pen. Per. Indonesia, 8(2): 7788.

Haryadi, S., Suryodiputro I.N.N., dan Widigdo B. 1992. Limnologi. Penuntun praktikum dan metode analisa air. Institut Pertanian Bogor. Fak. Perikanan, 57 pp.

Hily, C., Guinet C., and Ura J.F. 1994. Biodiversity of intertidal macrobenthic assemblages in the Iroise M.A.B reserve (Brittany France) in Marine Biodiversity: Causes and Concequences. The Marine Biological Association $30^{\text {th }}-2^{\text {nd }}$ September 1994 University of York, UK. 52 pp.

Kahar, A. Hanafi, F. Cholik, dan S. Tonnek. 1991. Evaluasi produktivitas perairan pantai bagi pengembangan tata ruang pantai. Dalam Suparno, S. Wibowo, A.M. Angawati, dan R. Arifudin (Eds.). Prosiding Pertemuan Teknis Pelestarian Lingkungan Hidup Perikanan. Jakarta, 11 Februari 1991. Pusat Penelitian dan Pengembangan Perikanan. Departeman Pertanian. Jakarta, p. 35-49.

Lind, O.T. 1991. Handbook of Common Methods in Limnology. C.V Mosby Company St. Louis.

Menon, R.G. 1973. Soil and Water Analysis. A laboratotry manual for the analysis of soil and water. FAO. United Nations Development Programme, $91 \mathrm{pp}$.

Newel, G.E. And R.C. Newel. 1977. Marine Plankton. Hutchinson, London, $244 \mathrm{pp}$.

Odum, E.P. 1963. Ecology. Second Edition. Holt, Rinehart, and Windston, Inc Allrights Reserve, $243 \mathrm{pp}$.

Pirzan, A.M., Gunarto, Daud R., dan Burhanuddin. 2001. Hubungan antara bahan organik, tekstur dan keragaman makrobenthos di kawasan tambak dan mangrove. Laporan Penelitian Balai Penelitian Perikanan Pantai. Maros.

Pirzan, A.M. dan Gunarto. 2001. Keragaman makrobentos dalam hubungannya dengan substrat di kawasan tambak, Kabupaten Mamuju. Laporan Penelitian. Balai Penelitian Perikanan Pantai Maros.

Pirzan, A.M., Gunarto, and Utojo. 2003. Plankton Diversity and Relationship with Phosphate in Brackishwater Pond of South Sulawesi. International Seminar on Marine and Fisheries. Agency for Marine and Fisheries Research. Ministry of Marine Affairs and Fisheries.

Purwadhi, S. Hardiyanti, Susanto, dan Hidayat. 1997. Penggunaan data inderaja satelit dan sistem informasi geografis (SIG) untuk perencanaan dan 
pengelolaan tata ruang wilayah. Dipersentasikan dalam Seminar Open House LAPAN dalam Rangka Tahun Kebangkitan IPTEK Nasional, Jakarta 5-7 Agustus 1997.

Quijon, P. and E. Jaranillo. 1993. Temporal variability in the intertidal macroinfauna in the Queule Rever Estuary, South-Central Chilie. Estuarin Coastal and Shelf Science, 37: 655-667.

Rachmansyah, Usman, dan D.S. Pongsapan. 2003. Pendugaan beban limbah budidaya bandeng dalam keramba jaring apung di laut. J. Pen. Per. Indonesia, $9(2): 65-76$.

Samuel, Z. Nasution, dan Akrim. 1995. Kelimpahan dan komposisi fitoplankton di DAS Batanghari bagian hilir, Provinsi Jambi. J. Pen. Per. Indonesia, 1(2): 3947.
Stirn, J. 1981. Manual Methods in Aquatic Invironment Research. Part 8 Ecological Assessment of Pollution Effects. FAO, Rome, 70 pp.

Ueda, N., H. Tsutsumi, M. Yamada, R. Takeuchi, and K. Kido. 1994. Recovery of the marine bottom environment of Japanese Bay. Marine Pollution Bulletin No. 28.

Widodo, J. 1997. Biodiversitas sumber daya perikanan laut peranannya dalam pengelolaan terpadu wilayah pantai. Dalam Mallawa, A., Syam R., Naamin N., Nurhakim S., Kartamihardja E.S., Poernomo A., dan Rachmansyah (Eds.). Prosiding Simposium Perikanan Indonesia 11 , Ujung Pandang 2-3 Desember 1997.

Yamaji, Y. 1976. Illustration of Marine Plankton. Hoikush Publishing Co. Ltd. Osaka, Japan. 